\title{
The Influence of Political Connection on Tax Avoidance
}

\author{
Zaga Kresna Pratama Putra ${ }^{1^{*}}$, Novrys Suhardianto ${ }^{2}$ \\ Accounting Department, Economics and Business Faculty, Universitas Airlangga, \\ Jalan Airlangga 4-6, Surabaya 60115, Indonesia \\ ${ }^{*}$ Corresponding author; Email: 1*zaga.kresna.pratama-2016@feb.unair.ac.id, 2novrys@feb.unair.ac.id
}

\begin{abstract}
The upper echelon theory and rent-seeking theory propose conflicting arguments related to the relationship between a firm's political connection and tax avoidance. This research aims to examine the relationship between a firm's political connection and tax avoidance. The 1,079 samples used in this research are public companies with positive income in the 20142018 period. By using regression analysis, this research finds that political connection has a negative relationship with tax avoidance, implying that political connection increases tax payment. This research contributes to providing supporting evidence for upper echelon theory by finding that management's political experience or the intention to maintain a positive image of politically connected management improves tax obedience.
\end{abstract}

Keywords: Tax avoidance; political connection; upper echelon theory, rent-seeking theory.

\section{INTRODUCTION}

Indonesia's tax revenue has failed to meet the target in the last 5 years [15]. From 2014 to 2018, 2014 is the only year with the highest revenue percentage [23]. The tax amnesty in 2016 and 2017 has also failed to achieve the target [1].

The non-optimal tax revenue can be caused by firms' tax avoidance. Tax avoidance is a term used to describe legal arrangements of taxpayer affairs to minimize tax liability [26]. Tax avoidance can be explained with several factors such as debt rate [8], firm size, and corporate transparency [6].

Firm management's political connection is one of the many factors that can influence tax avoidance. Firms that have political connections or officials or people who hold important positions in the government are indicated to receive special treatments from the government [9]. [9] identifies firms as having political connections if one of their main shareholder (at least 10\% of voting rights) or one of their leaders (CEO, president, vice president, chairman, or secretary) are members of the state parliament, or have relations with politicians or political parties. [12] also explains that a military officer can also be categorized as a criterion of political connection because it has a role in governance. This research is contributing by serving evidence of the relationship between political connection and tax avoidance.

Several previous studies find that the political connection has a positive relationship with tax avoidance [4], [16], [19]. Firms use their political connection to receive several benefits [3]. In the concept of taxes, political connections can be used to get access to changes in tax policy so that the firms can make better tax planning in anticipation of possible tax rate increases [19]. The demand for the company's transparency will be high but it can be solved by using their political connection to reduce the demand for transparency from the regulators [4]. A firm's political connection may protect it from the risk of being checked by tax authorities [16]. With this privilege, firms with political connections tend to have a higher tax avoidance rate [16].

Different from previous research and findings, [18] finds that political connection has a negative relationship with tax aggressivity. A political connection makes the firms to be more careful in making decisions because it will affect their image as compliant taxpayers [18]. Indonesian government through the Minister of Finance Regulation No. 71/PMK.03/2010 on Low-Risk Taxable Entrepreneur Granted Preliminary Restitution of Tax Overpayment states that the firms that are owned by the government, both central and local, are defined as low-risk taxpayers because the government believes that those firms will not commit tax avoidance [20]. Political connections can also be the government's agent to regulate and observe the firms' corporate governance, including tax, while also helping the government program of increasing tax revenue [14].

\section{Political Connection and Tax Avoidance Activities}

In the realm of political connection, there are two interesting theories: the upper echelon theory and rent-seeking theory. These two theories have conflicting arguments because they see the political 
connection phenomenon from different perspectives.

\section{Upper-Echelon Theory}

The upper-echelon theory states that the top management its organization. The managerial background can predict the outcome of the choice of strategy and some performance level. [10] through Upper Echelon Theory states that the values and cognitive of the leaders reflect their chosen strategies and bring their idea and experience from their previous careers. Empirically, the upper echelon theory gives a hypothesis that the character of the upper echelon is a determinant of organizational decisions and performance.

Managements whose career is only in one organization tend to have a limited way of thinking because of their limited knowledge and experience. Executive management recruited from outside the firms tend to make changes to the organization's structure, procedure, and human resources than the executive managers promoted from the organization [5], [13].

The managements' experience in politics may affect the firms' strategy. Political experiences may relate to tax avoidance because the management can implement values and decisions that are relevant to their political experiences that will affect the firms' loyalty to the Government. Managements' loyalty to the Government will influence the firms' strategy to be less aggressive in minimizing their tax expense.

\section{Rent-Seeking Theory}

According to [22], rent-seeking is an act done by a group of entities with similar interest and seek to gain as many economic benefits as they can with the smallest effort, thus, these rent-seeking practices may give a big influence on economic growth as well as social welfare and the number of aboveaverage income in the competitive market that involves the bureaucrats, capital owners, politicians, and people who monopolize the profit by doing illegal actions and taking advantage of their power.

[17 states that the rent-seeking theory is a theory that is in line with the public choice theory where certain parties such as politicians, bureaucrat, or parties close with the government are considered as having self-interest. Related parties will negotiate to influence economic policy to gain benefits for their group, such as easy access to import and export, subsidies on products, or convenience on a regulation. Government regulations are used to hinder supply or increase in resources that resulted in an increase in income which in reality is not in line with increased productivity. A selfish manager will manipulate the company to increase his/her wealth [7]

Based on that theory, firms with political connections will benefit from it. If seen from this theory, firms place people with a connection to the government into their organizational structure, whether as directors or commissioners to gain benefits, such as planning to lower tax payment.

With these 2 explained theories, upper echelon and rent-seeking theory, as well as the evidence of the previous studies that find equally strong results, the following hypothesis is formulated:

H: Political Connection has a relationship with firms' tax avoidance.

\section{RESEARCH METHOD}

The research population of this study is every company in all industrial sectors listed on the Indonesia Stock Exchange from 2014 to 2018 with the number of observations reaching 2.425. From that number of observations, there are several mismatches with the research plan which resulted in the usage of purposive sampling for the selection of research samples as shown in Table 1. The final number of samples is 1.079 observations. The data variable of this research comes from the firms' annual report and the annual report audited from the official site of the Indonesia Stock Exchange. The data of this research use winsorize with an accuracy level of $1 \%$.

Table 1. Selection of Research Samples

\begin{tabular}{|c|c|c|}
\hline No. & Criteria & $\begin{array}{c}\text { Number of } \\
\text { Observation }\end{array}$ \\
\hline 1 & $\begin{array}{l}\text { All observations listed on } \\
\text { Indonesia Stock Exchange } \\
\text { in 2014-2018 }\end{array}$ & 2.425 \\
\hline 2 & $\begin{array}{l}\text { Firms engaged in the } \\
\text { property \& real estate as } \\
\text { well as mining industries }\end{array}$ & (262) \\
\hline 3 & $\begin{array}{l}\text { Observations that suffer } \\
\text { losses }\end{array}$ & (561) \\
\hline 4 & $\begin{array}{l}\text { Observations with GAAP } \\
\text { ETR }>1 \text {, Current ETR }>1 \text {, } \\
\text { Cash ETR }>1\end{array}$ & (219) \\
\hline 5 & $\begin{array}{l}\text { Observations with GAAP } \\
\text { ETR }<0 \text {, Current ETR }<0 \text {, } \\
\text { Cash ETR }<0\end{array}$ & (304) \\
\hline & Total & 1.079 \\
\hline
\end{tabular}

The definition of the operational variables used in this research can be seen in Table 2. This research uses the multiple linear regression analysis to determine the relationship between the independent variable and the dependent variable and is used to construct equations that can make predictions. The measurement of tax avoidance is adopted from the research of [11]. 
Table 2. Operational Variables Definition

\begin{tabular}{|c|c|c|}
\hline $\begin{array}{c}\text { Variable } \\
\text { Types }\end{array}$ & $\begin{array}{l}\text { Variable } \\
\text { Names }\end{array}$ & $\begin{array}{l}\text { Measurement } \\
\text { Description }\end{array}$ \\
\hline \multicolumn{2}{|c|}{$\begin{array}{ll}\text { Independent } & \text { Political } \\
\text { Variable } & \text { Connection } \\
& \left(\mathrm{PCON}_{\mathrm{i}, \mathrm{t}}\right)\end{array}$} & $\begin{array}{l}\text { Firms are categorized as having } \\
\text { political connections if one of their } \\
\text { owners, the board of directors, or } \\
\text { board of commissioners are active } \\
\text { or ex-officials in the government } \\
\text { and military and are affiliated } \\
\text { with a political party [12]. }\end{array}$ \\
\hline \multirow[t]{3}{*}{$\begin{array}{l}\text { Dependent } \\
\text { Variable }\end{array}$} & $\begin{array}{l}\text { GAAP ETR } \\
\left.\text { (SAKETR } \mathrm{S}_{\mathrm{i}, \mathrm{t}}\right)\end{array}$ & $\begin{array}{l}\text { Total tax divided by the amount } \\
\text { of profit before tax[11] }\end{array}$ \\
\hline & $\begin{array}{l}\text { Current ETR } \\
\text { (CURRETR }_{\mathrm{i}, \mathrm{t}} \text { ) }\end{array}$ & $\begin{array}{l}\text { Current tax expense divided by } \\
\text { total profit before tax [11] }\end{array}$ \\
\hline & $\begin{array}{l}\text { Cash ETR } \\
\left.\text { (CASHETR }{ }_{i, t}\right)\end{array}$ & $\begin{array}{l}\text { Total cash tax paid divided by } \\
\text { profit before tax[11] }\end{array}$ \\
\hline \multirow[t]{8}{*}{$\begin{array}{l}\text { Control } \\
\text { Variable }\end{array}$} & $\begin{array}{l}\text { Return on Asset } \\
\left(\mathrm{ROA}_{\mathrm{i}, \mathrm{t}}\right)\end{array}$ & $\begin{array}{l}\text { Net profit divided by total assets } \\
\text { [2] }\end{array}$ \\
\hline & $\begin{array}{l}\text { Ukuran } \\
\text { perusahaan } \\
\text { (SIZE }\end{array}$ & $\begin{array}{l}\text { Natural logarithm of total assets } \\
\text { [14] }\end{array}$ \\
\hline & Leverage $\left(\mathrm{LEV}_{\mathrm{i}, \mathrm{t}}\right)$ & $\begin{array}{l}\text { Total liabilities divided by total } \\
\text { assets [29] }\end{array}$ \\
\hline & $\begin{array}{l}\text { Debt to Equity } \\
\text { Ratio }\left(\mathrm{DER}_{\mathrm{i}, \mathrm{t}}\right)\end{array}$ & $\begin{array}{l}\text { Total liabilities divided by total } \\
\text { equity [21] }\end{array}$ \\
\hline & $\begin{array}{l}\text { Market to Book } \\
\text { Value }\left(\mathrm{MTBV}_{\mathrm{i}, \mathrm{t}}\right)\end{array}$ & $\begin{array}{l}\text { Share price multiplied by the } \\
\text { number of shares then divided by } \\
\text { total equity [25] }\end{array}$ \\
\hline & $\begin{array}{l}\text { The proportion of } \\
\text { Independent } \\
\text { Board of } \\
\text { Commissioners } \\
\left.\text { (INDP }_{i, t}\right)\end{array}$ & $\begin{array}{l}\text { The number of independent } \\
\text { commissioners divided by total } \\
\text { commissioners [18] }\end{array}$ \\
\hline & $\begin{array}{l}\text { Institutional } \\
\text { Ownership } \\
\left.\text { (INSOWN }_{\mathrm{i}, \mathrm{t}}\right)\end{array}$ & $\begin{array}{l}\text { Total shares owned by } \\
\text { institutional divided with total } \\
\text { shares[18] }\end{array}$ \\
\hline & $\begin{array}{l}\text { Managerial } \\
\text { Ownership } \\
\left(\text { MOWN }_{\mathrm{i}, t}\right)\end{array}$ & $\begin{array}{l}\text { Total management shares } \\
\text { divided by total shares [18] }\end{array}$ \\
\hline
\end{tabular}

The regression model for testing the hypothesis is formulated with the 3 models below:

$\begin{aligned} \text { (1) SAKETRi, } t= & \alpha+\beta_{1} P C O N i, t+ \\ & \beta 2 R O A i, t+\beta 3 S I Z E i, t+ \\ & \beta 4 L E V i, t+\beta 5 D E R i, t+ \\ & \beta 6 M T B V i, t+\beta 7 I N D P i, t+ \\ & \beta 8 M O W N i, t+ \\ & \beta 9 I N S O W N i, t+\varepsilon i, t \\ \text { (2) CURRETRi, }= & \alpha+\beta_{1} P C O N i, t+ \\ & \beta 2 R O A i, t+\beta 3 S I Z E i, t+ \\ & \beta 4 L E V i, t+\beta 5 D E R i, t+ \\ & \beta 6 M T B V i, t+\beta 7 I N D P i, t+ \\ & \beta 8 M O W N i, t+ \\ & \beta 9 I N S O W N i, t+\varepsilon i, t \\ & \alpha+\beta 1 P C O N i, t+ \\ & \beta 2 R O A i, t+\beta 3 S I Z E i, t+ \\ & \beta 4 L E V i, t+\beta 5 D E R i, t+ \\ & \beta 6 M T B V i, t+ \\ & \beta 7 I N D P i, t+\beta 8 M O W N i, t+ \\ & \beta 9 I N S O W N i, t+\varepsilon i, t\end{aligned}$

A T-test or correlation test is done to discover the differences and relationships between variables. The coefficient of determination test is done to discover the amount of influence from the independent variable to the dependent variable. This research also uses the Robustness test to analyze the resilience of the results. The Robustness test is conducted using 2

Method (1) is conducted by regressing the number of people with political connections and tax avoidance rate. The variable used in this test is RASIOPCON. This test aims to prove whether the number of firms' managements with political connections if counted proportionally, will be related to the tax avoidance rate.

Method (2) is done by classifying the people on top management with political connections into 3 parts based on their position which are commissioners, independent commissioners, or directors. The POSPCON $1_{i, t}$ variable shows the existence of political connection in the commissioners position, POSPCON2 $2_{\mathrm{i}, \mathrm{t}}$ shows political connections in the independent commissioners' position, and POSPCON 3 i,t shows the political connection in the director position. This test aims to discover the position in which political connection has a relationship with tax avoidance.

\section{RESULT AND DISCUSSION}

\section{Descriptive Statistic Analysis}

The result of the descriptive statistic analysis (Table 3) shows that the SAKETR and CURRETR variables have an average $>0,25$ which indicates the presence of tax avoidance activity because the tax rate for companies is $25 \%$ of taxable income. CASHETR shows a different result, with the average value of 0,26 which indicates paying greater tax than the stipulated rate.

Table 3. Descriptive Statistics

\begin{tabular}{lrrrr}
\hline Variable & Mean & $\begin{array}{c}\text { Std. } \\
\text { Dev. }\end{array}$ & Min. & Maks. \\
\hline SAKETR & 0.24 & 0.13 & 0.00 & 0.84 \\
CURRETR & 0.21 & 0.14 & 0.00 & 0.67 \\
CASHETR & 0.26 & 0.20 & 0.00 & 0.91 \\
ROA & 0.07 & 0.07 & 0.00 & 0.42 \\
LEV & 0.51 & 0.25 & 0.01 & 1.07 \\
DER & 1.81 & 2.28 & -1.49 & 10.55 \\
MTBV & 2.55 & 4.60 & -0.12 & 34.95 \\
SIZE & 28.88 & 1.82 & 24.90 & 33.47 \\
MOWN & 0.03 & 0.09 & 0.00 & 0.50 \\
INSOWN & 0.67 & 0.23 & 0.00 & 0.99 \\
INDP & 0.43 & 0.12 & 0.22 & 0.80 \\
\hline
\end{tabular}

The descriptive statistic for the political connection variable is shown in Table $4.40,3 \%$ of the observation has an indication of having a political connection. Most of the samples does not have a political connection. 
Table 4. PCON Descriptive Statistics

\begin{tabular}{lcc}
\hline PCON & Frequency & \% \\
\hline Without Connection & 644 & 59,7 \\
With Political Connection & 435 & 40,3 \\
\hline Total & 1.079 & 100 \\
\hline
\end{tabular}

Table 5 shows the distribution of political connections across the observed period. The data in table 5 indicates that there is no notable spike in the number of firms' political connections.

Table 5. Distribution of political connection on each year

\begin{tabular}{cccc}
\hline \multirow{2}{*}{ Year } & \multicolumn{2}{c}{ PCON } & \multirow{2}{*}{ Total } \\
\cline { 2 - 3 } & 0 & 1 & \\
\hline 2014 & 177 & 105 & 282 \\
2015 & 110 & 73 & 183 \\
2016 & 151 & 96 & 247 \\
2017 & 83 & 67 & 150 \\
2018 & 123 & 94 & 217 \\
\hline Total & 644 & 435 & 1079 \\
\hline
\end{tabular}

Table 6 presents the industries that have a political connection; the bank shows the highest number with 68 firms while metal and allied products as well as plastics and packaging sit in the last place with 1 firm each.

The test is continued with a t-test. The result of this t-test can be seen in Table 7, which shows that firms with political connections show differences in the amount of tax paid, firms' characteristics, and corporate governance from the firms with no political connection. This result shows that firms with political connections have a larger value of ETR, which indicates that firms with political connections are more obedient as taxpayers.

The next test is the correlation test. The correlation test uses the pairwise correlation with a significance level of $5 \%$ and $10 \%$. The result of this test can be seen in the research attachment. The dependent variables that are measured with SAKETR, CURRETR, and CASHETR all have positive coefficient value and own star mark, which shows that these variables have significant positive correlations at a 5\% rate with other ETR measurements, for example, if SAKETR increases then CURRENTETR and CASHETR will increase too. The coefficient value that is spread from 0,411 to 0,574 in all ETR shows a sufficient level of relationship.

The independent variable of this research, PCON, has the star mark $\left(^{*}\right)$ on its coefficient number if connected to the SAKETR variable, this shows that political connection correlates with a $10 \%$ significance level on this research's dependent variable. PCON's coefficient number towards the ETR variable is also at 0,060 which means the political connection variable correlates with the ETR variable.
Table 6. Distribution of Political Connection in Industry

\begin{tabular}{lr}
\hline Industry & Freq. \\
\hline Bank & 68 \\
Wholesale & 36 \\
Retail Trade & 26 \\
Advertising, Printing, and Media & 24 \\
Transportation & 23 \\
Pharmaceuticals & 20 \\
Plantation & 19 \\
Food and Beverages & 18 \\
Financial Institution & 17 \\
Tourism, Restaurant, and Hotel & 16 \\
Automotive and Components & 16 \\
Cement & 15 \\
Investment Company & 11 \\
Cable & 11 \\
Animal Feed & 10 \\
Health Care & 9 \\
Insurance & 9 \\
Other Finance Industry & 8 \\
Cosmetics and Household & 74 \\
Footwear & 7 \\
Computer and Services & 7 \\
Securities Company & 60 \\
Telecommunication & 6 \\
Toll Road, Airport, Harbor, and Allied Products & 6 \\
Fishery & 6 \\
Pulp and Paper & 6 \\
Non-Building Construction & 6 \\
Tobacco Manufacturers & 6 \\
Others Trade, Service \& Investment & 6 \\
Energy & 5 \\
Textile, Garment & 5 \\
Wood Industries & 4 \\
Chemicals & 4 \\
Metal and Allies Products & 3 \\
Plastic and Packaging & 2 \\
Total & 2 \\
Average cross-industry political connections \\
\hline
\end{tabular}

Table 7. T-Test Result

\begin{tabular}{|c|c|c|c|}
\hline Variable & Not Connected & Connected & diff \\
\hline \multicolumn{4}{|c|}{ Panel A Tax Avoidance } \\
\hline SAKETR & .237 & .244 & -.007 \\
\hline CURRETR & .200 & .218 & $-.017 * *$ \\
\hline CASHETR & .258 & .264 & -.006 \\
\hline \multicolumn{4}{|c|}{ Panel B Control Variabel } \\
\hline ROA & 0.059 & 0.073 & $-.008^{* * * *}$ \\
\hline LEV & 0.477 & 0.547 & $-.069 * * *$ \\
\hline DER & 1.531 & 2.228 & $-.697 * * *$ \\
\hline MTBV & 1.862 & 3.576 & $-1.714^{* * *}$ \\
\hline SIZE & 28.334 & 29.686 & $-1.352^{* * *}$ \\
\hline MOWN & 0.038 & 0.025 & .013 \\
\hline INSOWN & 0.670 & 0.666 & .003 \\
\hline INDP & 0.419 & 0.450 & $-.031^{* * * *}$ \\
\hline
\end{tabular}

Some of the control variables in this research also have a significant yet weak correlation with their independent variables. The control variables 
with correlations are ROA and LEVgthg. This happens because profit is the source of tax calculation and thus has a significant relation, debt rate also has a significant relation with tax because debt financing is not taxed and the interest expense can be deducted for tax calculations.

From the correlation test, this research finds a correlation that there is a fairly weak correlation between the independent variable and the research's dependent variable with a significance level of $10 \%$. The research continues with multiple linear regression testing to find a more accurate result.

This multiple linear regression test serves to determine the relationship between the independent, dependent, and control variables. The result can be seen in Table 8 .

Table 8. Multiple Linear Regression Test Result

\begin{tabular}{lccc}
\hline Variables & Saketr & Curretr & Cashetr \\
\hline PCON & 0.01 & $0.02^{* * *}$ & 0.02 \\
ROA & $(0.01)$ & $(0.01)$ & $(0.01)$ \\
& $-0.41^{* * *}$ & $-0.34^{* * *}$ & $-0.55^{* * *}$ \\
LEV & $(0.06)$ & $(0.07)$ & $(0.09)$ \\
& $0.09^{* * *}$ & -0.00 & $0.07^{*}$ \\
DER & $(0.00)$ & $(0.00)$ & $(0.00)$ \\
& -0.00 & -0.00 & 0.00 \\
MTBV & $(0.00)$ & $(0.00)$ & $(0.00)$ \\
& $0.00^{*}$ & $0.00^{*}$ & 0.00 \\
SIZE & $(0.00)$ & $(0.00)$ & $(0.00)$ \\
& $-0.00^{* * *}$ & -0.00 & -0.00 \\
MOWN & $(0.00)$ & $(0.00)$ & $(0.00)$ \\
& 0.07 & 0.08 & 0.04 \\
INSOWN & $(0.05)$ & $(0.05)$ & $(0.07)$ \\
& 0.02 & 0.01 & 0.01 \\
INDP & $(0.02)$ & $(0.02)$ & $(0.03)$ \\
& -0.02 & $-0.03^{*}$ & 0.01 \\
Constant & $(0.04)$ & $(0.04)$ & $(0.05)$ \\
& $0.26^{* * *}$ & $0.25^{* * *}$ & $0.22^{* *}$ \\
Observations & $(0.08)$ & $(0.09)$ & $(0.13)$ \\
Number of SIC & 1,079 & 1,079 & 1,079 \\
Dummy Tahun & 42 & 42 & 42 \\
Adj. R ${ }^{2}$ & Yes & Yes & Yes \\
\hline Standard & 0.0524 & 0.0187 & 0.0228 \\
\hline
\end{tabular}

Standard error in parentheses

$* * * \mathrm{p}<0.01,{ }^{* *} \mathrm{p}<0.05,{ }^{*} \mathrm{p}<0.1$

Table 8 shows that political connection (PCON) has a positive relationship with tax avoidance (ETR), which is shown through a positive and significant regression coefficient. Thus, the research hypothesis is accepted, a political connection has a negative relationship with tax avoidance, firms with political connections tend to avoid tax avoidance practices, or in other words, a political connection will increase the amount of tax paid to the state. This result is in line with the upper echelon theory hypothesis that the characteristics of a firm leader with political connection tend to be loyal to the government and the firm will eventually pay higher taxes after controlling the firm's profitability.

The research continues with the robustness test that uses the analysis method of classifying the top management with political connections into 3 parts according to their position: commissioners, independent commissioners, or directors. Table 9 serves the result.

Table 9 shows that the influence of political influence on tax avoidance only shows in the independent commissioners and directors using the CURRETR proxy.

This research hypothesizes that political connection influences tax avoidance. The result of the multiple linear regression test shows that independent commissioners with political connections have a 0,02 coefficient on CURRETR with a $10 \%$ significance level and directors with political connections have a 0,04 coefficient and 5\% significance level. This means firms with political connections pay more taxes than the firms with no political connection. The research hypothesis is accepted because a political connection has a positive relationship with firms' tax rates or in other words, has a negative relationship with tax avoidance activities.

The Robustness test result in Table 9 also supports this research. The result shows that political connection has a positive influence on the amount of taxes that the firms paid or has a negative relationship with tax avoidance rate. Political connection still has a positive relationship with tax avoidance rate even with a coefficient and significance level that are different from the main analysis. The findings on the main analysis and the robustness test bring evidence that supports the upper echelon theory and not the rent-seeking theory. The positive relationship between political connection and tax compliance indicates that the characteristics of the politicians in the top management influence the firms' decision by paying higher taxes because of the loyalty of the (ex) politician to the state.

The findings on this research support the research of [18], where firms with political connection will protect their image as Compliant Taxpayers aside from protecting the image of the politicians in the management structure and thus will be careful in making a decision and comply with the tax regulation. The findings of this result also support the argument that says that management with political connection also become the government agent in managing and overseeing corporate governance, including taxation [14]. In other words, this research is in line with the Minister of Finance Regulation No. 71/PMK.03/ 
Table 9. Cross-Position Political Connection Robustness Test Result

\begin{tabular}{|c|c|c|c|c|c|c|c|c|c|}
\hline VARIABLES & $\begin{array}{c}\text { Comm. } \\
\text { SAKETR }\end{array}$ & $\begin{array}{c}\text { Indp. } \\
\text { Comm. } \\
\text { SAKETR }\end{array}$ & $\begin{array}{c}\text { Directors } \\
S A K E T R\end{array}$ & $\begin{array}{c}\text { Comm. } \\
\text { CURRETR }\end{array}$ & $\begin{array}{c}\text { Indp. } \\
\text { Comm. } \\
\text { CURRETR }\end{array}$ & $\begin{array}{c}\text { Directors } \\
\text { CURRETR }\end{array}$ & $\begin{array}{c}\text { Comm. } \\
\text { CASHETR }\end{array}$ & $\begin{array}{c}\text { Indp. } \\
\text { Comm. } \\
\text { CASHETR }\end{array}$ & $\begin{array}{c}\text { Directors } \\
\text { CASHETR }\end{array}$ \\
\hline$\overline{P O S P C O N}$ & $\begin{array}{c}\mathbf{0 . 0 1} \\
(0.01)\end{array}$ & $\begin{array}{l}\mathbf{- 0 . 0 0} \\
(0.01)\end{array}$ & $\begin{array}{c}\mathbf{0 . 0 3} \\
(0.02)\end{array}$ & $\begin{array}{c}\mathbf{0 . 0 0} \\
(0.01)\end{array}$ & $\begin{array}{l}\mathbf{0 . 0 2 *} \\
(0.01)\end{array}$ & $\begin{array}{c}\mathbf{0 . 0 4} \text { ***; } \\
(0.02)\end{array}$ & $\begin{array}{l}-0.00 \\
(0.02)\end{array}$ & $\begin{array}{l}\mathbf{- 0 . 0 0} \\
(0.01)\end{array}$ & $\begin{array}{c}\mathbf{0 . 0 1} \\
(0.03)\end{array}$ \\
\hline$R O A$ & $\begin{array}{c}-0.41^{* * *} \\
(0.07)\end{array}$ & $\begin{array}{c}-0.41^{* * * *} \\
(0.07)\end{array}$ & $\begin{array}{c}-0.40^{* * * *} \\
(0.07)\end{array}$ & $\begin{array}{c}-0.34^{* * * *} \\
(0.08)\end{array}$ & $\begin{array}{c}-0.35^{* * * *} \\
(0.08)\end{array}$ & $\begin{array}{c}-0.33^{* * * *} \\
(0.08)\end{array}$ & $\begin{array}{c}-0.54^{* * * *} \\
(0.11)\end{array}$ & $\begin{array}{c}-0.55^{* * *} \\
(0.11)\end{array}$ & $\begin{array}{c}-0.54^{* * * *} \\
(0.11)\end{array}$ \\
\hline$L E V$ & $\begin{array}{c}0.09^{* * *} \\
(0.02)\end{array}$ & $\begin{array}{c}0.09^{* * * *} \\
(0.02)\end{array}$ & $\begin{array}{c}0.10^{* * *} \\
(0.02)\end{array}$ & $\begin{array}{l}-0.00 \\
(0.03)\end{array}$ & $\begin{array}{c}0.00 \\
(0.03)\end{array}$ & $\begin{array}{c}0.00 \\
(0.03)\end{array}$ & $\begin{array}{l}0.06^{*} \\
(0.04)\end{array}$ & $\begin{array}{l}0.07^{*} \\
(0.04)\end{array}$ & $\begin{array}{l}0.07^{*} \\
(0.04)\end{array}$ \\
\hline$D E R$ & $\begin{array}{l}-0.00 \\
(0.00)\end{array}$ & $\begin{array}{c}-0.00^{* * *} \\
(0.00)\end{array}$ & $\begin{array}{l}-0.00 \\
(0.00)\end{array}$ & $\begin{array}{l}-0.00 \\
(0.00)\end{array}$ & $\begin{array}{l}-0.00 \\
(0.00)\end{array}$ & $\begin{array}{l}-0.00 \\
(0.00)\end{array}$ & $\begin{array}{c}0.00 \\
(0.00)\end{array}$ & $\begin{array}{c}0.00 \\
(0.00)\end{array}$ & $\begin{array}{c}0.00 \\
(0.00)\end{array}$ \\
\hline$M T B V$ & $\begin{array}{l}0.00^{* * *} \\
(0.00)\end{array}$ & $\begin{array}{l}0.00^{* * *} \\
(0.00)\end{array}$ & $\begin{array}{l}0.00^{*} \\
(0.00)\end{array}$ & $\begin{array}{l}0.00^{* * *} \\
(0.00)\end{array}$ & $\begin{array}{l}0.00 * \\
(0.00)\end{array}$ & $\begin{array}{l}0.00^{*} \\
(0.00)\end{array}$ & $\begin{array}{c}0.00 \\
(0.00)\end{array}$ & $\begin{array}{c}0.00 \\
(0.00)\end{array}$ & $\begin{array}{c}0.00 \\
(0.00)\end{array}$ \\
\hline SIZE & $\begin{array}{l}-0.00 \\
(0.00)\end{array}$ & $\begin{array}{l}-0.00 \\
(0.00)\end{array}$ & $\begin{array}{l}-0.00 \\
(0.00)\end{array}$ & $\begin{array}{c}0.00 \\
(0.00)\end{array}$ & $\begin{array}{l}-0.00 \\
(0.00)\end{array}$ & $\begin{array}{c}0.00 \\
(0.00)\end{array}$ & $\begin{array}{c}0.00 \\
(0.00)\end{array}$ & $\begin{array}{c}0.00 \\
(0.00)\end{array}$ & $\begin{array}{c}0.00 \\
(0.00)\end{array}$ \\
\hline$M O W N$ & $\begin{array}{c}0.07 \\
(0.05)\end{array}$ & $\begin{array}{c}0.07 \\
(0.05)\end{array}$ & $\begin{array}{c}0.07 \\
(0.05)\end{array}$ & $\begin{array}{c}0.08 \\
(0.05)\end{array}$ & $\begin{array}{c}0.08 \\
(0.05)\end{array}$ & $\begin{array}{c}0.08 \\
(0.05)\end{array}$ & $\begin{array}{c}0.04 \\
(0.08)\end{array}$ & $\begin{array}{c}0.04 \\
(0.07)\end{array}$ & $\begin{array}{c}0.04 \\
(0.07)\end{array}$ \\
\hline INSOWN & $\begin{array}{c}0.02 \\
(0.02)\end{array}$ & $\begin{array}{c}0.01 \\
(0.02)\end{array}$ & $\begin{array}{l}0.02 \\
(0.02)\end{array}$ & $\begin{array}{c}0.01 \\
(0.02)\end{array}$ & $\begin{array}{c}0.01 \\
(0.02)\end{array}$ & $\begin{array}{c}0.01 \\
(0.02)\end{array}$ & $\begin{array}{c}0.01 \\
(0.03)\end{array}$ & $\begin{array}{c}0.01 \\
(0.03)\end{array}$ & $\begin{array}{c}0.01 \\
(0.03)\end{array}$ \\
\hline$I N D P$ & $\begin{array}{l}-0.02 \\
(0.04)\end{array}$ & $\begin{array}{l}-0.02 \\
(0.04)\end{array}$ & $\begin{array}{l}-0.02 \\
(0.04)\end{array}$ & $\begin{array}{l}-0.02 \\
(0.04)\end{array}$ & $\begin{array}{l}-0.03 \\
(0.04)\end{array}$ & $\begin{array}{l}-0.02 \\
(0.04)\end{array}$ & $\begin{array}{c}0.00 \\
(0.05)\end{array}$ & $\begin{array}{c}0.01 \\
(0.05)\end{array}$ & $\begin{array}{c}0.01 \\
(0.05)\end{array}$ \\
\hline Constant & $\begin{array}{c}0.25^{* * * *} \\
(0.08)\end{array}$ & $\begin{array}{c}0.24^{* * * *} \\
(0.08)\end{array}$ & $\begin{array}{c}0.25^{* * * *} \\
(0.08)\end{array}$ & $\begin{array}{c}0.21^{* * *} \\
(0.08)\end{array}$ & $\begin{array}{c}0.25^{* * *} \\
(0.09)\end{array}$ & $\begin{array}{c}0.22^{* * * *} \\
(0.09)\end{array}$ & $\begin{array}{l}0.21^{*} \\
(0.12)\end{array}$ & $\begin{array}{c}0.21 \\
(0.13)\end{array}$ & $\begin{array}{l}0.22^{*} \\
(0.12)\end{array}$ \\
\hline Observations & 1,079 & 1,079 & 1,079 & 1,079 & 1,079 & 1,079 & 1,079 & 1,079 & 1,079 \\
\hline Number of sic & 42 & 42 & 42 & 42 & 42 & 42 & 42 & 42 & 42 \\
\hline Dummy Tahun & Yes & Yes & Yes & Yes & Yes & Yes & Yes & Yes & Yes \\
\hline Adj. $R^{2}$ & 0,0649 & 0,0642 & 0,0678 & 0,0208 & 0,0246 & 0,0251 & 0,0159 & 0,0147 & 0,0151 \\
\hline
\end{tabular}

Standard error inside the parentheses

$* * * \mathrm{p}<0.01,{ }^{* *} \mathrm{p}<0.05,{ }^{*} \mathrm{p}<0.1$

2010 on Low-Risk Taxable Entrepreneur Granted Preliminary Restitution of Tax Overpayment, which states that firms with connection to the government are considered as low-risk Taxpayers [20]. This finding also supports the Upper Echelon theory which argues that the experience from military and politics can influence the management's decision in determining their tax strategy. The military or political experience that has a connection with the state's interest shapes loyalty to the states, thus the connection with retired military officers or officials/ex-officials will reduce tax avoidance activities.

The result of this research is different from the research done by [27] and [30]. This can happen because of the use of different data samples, both studies focus on state-owned enterprises in Indonesia. The result of this research is also different from the research conducted by [2], [16], [28], and does not support the rent-seeking theory in the Indonesian context during the observation period because there may be political behavior characteristics that are different from other countries.

This research also uses control variables that represent firms' characteristics and corporate governance. The control variables that represent firms' characteristics are profitability (ROA), solvability (LEV and DER), market to book ratio (MTBV), and firm size (SIZE). The control variables that represent corporate governance are management-owned shares (MOWN), institutional-owned shares (INSOWN), and the proportion of independent commissioners (PROPKINDEP). ROA has a significant negative value on ETR, which means an increase in profits will raise the possibility of tax avoidance rate and must be included in the regression analysis of tax avoidance [2]. LEV has a significant negative value that is in line with the research of [29]. DER has a significant negative value, in line with the research of [21]. MOWN has a significant positive value with tax avoidance, this happens because there is a consideration by the management about the firm's sustainability, which is in line with the research of [24]. MTBV, SIZE, INSOWN, and INDP are not proven to have a relationship with tax avoidance.

\section{CONCLUSION}

This research explains the relationship between political connection and tax avoidance of Indonesian firms from 2014 to 2018 . This research measures the ETR and management with political connections. The result of this research finds that political connection has a positive relationship with the amount of a firm's tax, this means that the existence of managements with political connection suppresses tax avoidance activities. This research supports the previous studies done by [14], [18], [20], [32]. 
This research has limitations, the result of this research should be interpreted carefully because of the research limitations. First, this research can only register the existence and the number of personnel with political connections inside of a firm and fail to observe the actual role of this personnel. Because of that, this research highly recommends future research to observe the actual role of the aforementioned personnel.

Secondly, although this research focuses on one period of regime rule, the political situation in 2014-2018 may have influenced the result of this research. Because of that, this research inserts a dummy year in the regression analysis to control the unobserved factors that could influence the result of the result in the observation year. An example of a political situation that may influence the result of this research is the fact that the reigning government is supported by a coalition party whose number of votes exceeds 50\% [31]. This may lead to a tendency for the politicians to support the government and may eventually bias the result of this research. Because of that, future research should analyze the changes in the effects of political connection on different regimes of power.

Thirdly, the measurement of tax avoidance using ETR is very common. However, ETR only measures the amount of tax expense paid by the firm in comparison with the recognized revenue. On the other hand, tax avoidance may have a wide spectrum starting from simple ones such as increasing deductible expenses, earning manipulation, or doing complex transactions. ETR only measures the outcome of the tax avoidance process that can be influenced by factors other than the firm's tax avoidance strategy such as regulation or the firm's financial condition.

This research finds that the presence of political connection increases the amount of the firm's tax that will in turn help the state's finances. Because of that, this research has a suggestion for the Indonesian government, especially the Director-General of Taxes, to encourage the people with political connections from both the military and government to join firms' management.

\section{REFERENCES}

[1] (2018, August 6). Retrieved from onlinepajak.com: https://www.online-pajak.com/taxamnesty-dan-tujuannya-di-indonesia

[2] Adhikari, A., Derashid, C., and Zhang, H. (2006). Public Policy, Political Connections, and Effective Tax Rates: Longitudinal Evidence from Malaysia. Journal of Accounting and Public Policy, 25(5), 574-595. doi:10.1016 /j.jaccpubpol.2006.07.001
[3] Brown, J., Drake, K., and Wellman, L. (2015). The Benefits of a Relational Approach to Corporate Political Activity: Evidence from Political Contributions to Tax Policymakers. The Journal of the American Taxation Association 37(1), 69-102. https://dx.doi.org/10. 2139/ssrn.2209373

[4] Butje, S., dan Tjondro, E. (2014). Pengaruh Karakter Eksekutif dan Koneksi Politik Terhadap Tax Avoidance. Tax \& Accounting Review, 4(2), 1-9.

[5] Carlson, R. O., School superintendents: Career and performanc, Columbia., Merrill, 1972.

[6] Chen, X., Hu, N., and Wang X. (2014). Tax avoidance and firm value: evidence from China. Nankai Business Review International, 5(1), 25-42. doi: 10.1108/NBRI-10-2013-0037.

[7] Desai, M., and Dharmapala, D. (2006). Corporate Tax Avoidance And High-Powered Incentives. Journal of Financial Economics, 79(1), 145-179. doi:10.1016/j.jfineco.2005.02. 002.

[8] Lin, S., Tong, N. and Tucker, A.L. (2014). Corporate tax aggression and debt. Journal of Banking and Finance 40(1), 227-241.

[9] Faccio, M. (2006). Politically Connected Firms. The American Economic Review, 96(1), 369386. doi:10.1108/ARA-05-2016-0053

[10] Hambrick, D. C., and Mason, P. A. (1984). Upper Echelons: The Organization As a Reflection of Its Top Managers. Academy of Management Review, 2(9), 193-206.

[11] Hanlon, M., dan Heitzman, S. (2010). A Review of Tax Research. Journal of Accounting and Economics, 50(2-3), 127-178

[12] Harymawan, I. (2018). Why Do Firms Appoint Former Military Pearsonnel As Directors? Evidence of Loan Interest Rate in Militarily Connected Firms in Indonesia. Asian Review of Accounting, 26(1), 2-18. Retrieved from https://doi.org/10.1108/ARA-072016-0086

[13] Helmich, D., and Brown, W. B. (1972). Successor Type and Organizational Change in the Corporate Enterprise. Administrative Science Quarterly, 17(3), 371-381.

[14] Iswari, P., Sudaryono, E. A., dan Widarjo, W. (2019). Political Connection and Tax Aggresiveness: A Study on the State Owned Enterprise Registered in Indonesia Stock Exchange. Journal of International Studies, 12(1), 79-92. doi:10.14254/2071-8330.2019/21-1/5

[15] Kementerian Keuangan Republik Indonesia, Direktorat Jenderal Pajak. (2019). Laporan Keuangan Direktorat Jenderal Pajak: Tahun Anggaran 2018 Audited. 53.

[16] Kim, C., dan Zhang, L. (2016). Corporate Political Connections and Tax Aggresiveness. Contemporary Accounting Research, 33(1), 78114. doi:10.1111/1911-3846.12150. 
[17] Krueger, A. O. (1974). The Political Economy of the Rent-Seeking Society. The American Economic Review, 64 (3) 291-303. Retrieved from http://www.jstor.org/stable/1808883.

[18] Lestari, G., dan Putri, I. (2017). Pengaruh Corporate Governance, Koneksi Politik dan Leverage terhadap Penghindaran Pajak. EJurnal Akuntansi. 18(3), 2028-2054.

[19] Milyo, J., Primo, D., and Groseclose, T. (2017). Corporate PAC Campaign Contributions in Perspective. Business and Politics, 2(1), 75-88.

[20] Mulyani, S., Darminto, N. P. M. G. Wi Endang (2014). Pengaruh Karakteristik Perusahaan, Koneksi Politik dan Reformasi Perpajakan Terhadap Penghindaran Pajak. Jurnal Mahasiswa Perpajakan 2(1), 1-9.

[21] Richardson, G., Lanis, R. (2007). Determinants of variability in corporate effective tax rates and tax reform: Evidence from Australia. Journal of Accounting and Public Policy, 26. 689-704

[22] Olson, M. (1982). Rise and Decline of Nations: Economic Growth, Stagflation and Social Rigidities. New Haven and London: Yale University Press, $x i+273$ p.

[23] Panjaitan, J. Y., dan Fitri, H. (2019). Perkembangan Realisasi Penerimaan Perpajakan Periode 2013-2018 dan Target dalam RAPBN 2019. Pusat Kajian Anggaran, Badan Keahlian DPR RI.

[24] Cabello, O. G., Gaio, L. E., and Watrin, C. (2019). Tax avoidance in management-owned firms: evidence from Brazil. International Journal of Management Finance, 15(4), 580592. doi: 10.1108/IJMF-04-2018-0117.
[25] Justina, D. (2018). Pengaruh Firm Size dan Market to Book Ratio terhadap Return Portofolio. Jurnal Manajemen dan Bisnis Sriwijaya 15(2), 138-145. doi: 10.29259/jmbs.v15i2.5701

[26] Suandy, E., Perencanaan Pajak Edisi 6, Salemba Empat, 2, 15., Jakarta, 2017.

[27] Sudibyo, Y. A., and Jianfu, S. (2016). Political Connections, State Owned Enterprises and Tax Avoidance: An Evidence From Indonesia. Corporate Ownership and Control, 13(3), 279283.

[28] Wahab, E. A., Ariff, A. M., Marzuki, M. M., and Sanusi, Z. M. (2017). Political connections, corporate governance, and tax aggressiveness in Malaysia. Asian Review of Accounting, 25(3), 424-451. doi:10.1108/ARA05-2016-0053

[29] Wardani, D. K., and Purwanignrum, R. (2018). Pengaruh Karakteristik Perusahaan dan Corporate Social Responsibility Terhadap Penghindaran Pajak. Jurnal Riset Akuntansi dan Keuangan Fakultas Bisnis UKDW, 14(1). 1-13.

[30] Wicaksono, A. P. (2017). Koneksi Politik dan Agresivitas Pajak: Fenomena di Indonesia. Akuntabilitas: Jurnal Ilmu Akuntansi, 10(1), 167-180. doi:10.15408/akt.v10i1.5833

[31] Wikipedia. (2019, May 4). Retrieved from Koalisi Indonesia Hebat: https://id.wikipedia. org/wiki/Koalisi_Indonesia_Hebat

[32] Zhang, H., LI, W., and Jian, M. (2012). How Does State Ownership Affect Tax Avoidance? Evidence from China. Singapore Management University, School of Accountancy, 13-18. 
90 JURNAL AKUNTANSI DAN KEUANGAN, VOL. 22, NO. 2, NOVEMBER 2020: 82-90

\section{APPENDIX}

Hasil Uji Korelasi

Pairwise correlations

\begin{tabular}{|c|c|c|c|c|c|c|c|c|}
\hline Variables & (1) & (2) & (3) & (4) & (5) & (6) & (7) & (8) \\
\hline (1) SAKETR & 1.000 & & & & & & & \\
\hline (2) CURRETR & $0.441^{* * *}$ & 1.000 & & & & & & \\
\hline (3) CASHETR & $0.411^{* *}$ & $0.574 * *$ & 1.000 & & & & & \\
\hline (4) $\mathrm{PCON}$ & 0.028 & $0.060 * *$ & 0.015 & 1.000 & & & & \\
\hline (5) $\mathrm{ROA}$ & $-0.169 * *$ & $-0.071^{* *}$ & $-0.130 * *$ & $0.097 * *$ & 1.000 & & & \\
\hline (6) LEV & $0.109 * *$ & -0.036 & 0.021 & $0.139 * *$ & $-0.274^{* *}$ & 1.000 & & \\
\hline (7) DER & 0.045 & -0.046 & -0.022 & $0.150 * *$ & $-0.266^{* *}$ & $0.734^{* *}$ & 1.000 & \\
\hline (8) MTBV & -0.033 & 0.005 & -0.047 & $0.183^{* *}$ & $0.561^{* *}$ & 0.017 & 0.026 & 1.000 \\
\hline (9) SIZE & 0.031 & 0.008 & 0.005 & $0.364 * *$ & $-0.062^{* *}$ & $0.330 * *$ & $0.406^{* *}$ & 0.049 \\
\hline (10) MOWN & 0.016 & 0.033 & -0.006 & $-0.072^{* *}$ & -0.019 & $-0.114^{* *}$ & $-0.082^{* *}$ & $-0.052^{*}$ \\
\hline (11) INSOWN & 0.011 & -0.015 & -0.004 & -0.007 & 0.042 & $0.111^{* *}$ & $0.082^{* *}$ & 0.033 \\
\hline (12) INDP & -0.023 & $-0.063^{* *}$ & $-0.076^{* *}$ & $0.125^{* *}$ & -0.024 & $0.275^{* *}$ & $0.311^{* *}$ & $0.132^{* * *}$ \\
\hline
\end{tabular}

\begin{tabular}{lcccc}
\hline \multicolumn{1}{c}{ Variables } & $(9)$ & $\mathbf{( 1 0 )}$ & $\mathbf{( 1 1 )}$ & $\mathbf{( 1 2 )}$ \\
\hline (1) SAKETR & & & & \\
(2) CURRETR & & & & \\
(3) CASHETR & & & \\
(4) PCON & & & & \\
(5) ROA & & & & \\
(6) LEV & & & & \\
(7) DER & & & & \\
(8) MTBV & & & & \\
(9) SIZE & 1.000 & & & \\
(10) MOWN & $-0.133^{* *}$ & 1.000 & & \\
(11) INSOWN & $-0.017^{*}$ & $-0.503^{* *}$ & 1.000 & \\
(12) INDP & $0.164^{* *}$ & $-0.071^{*}$ & 0.029 & 1.000 \\
\hline
\end{tabular}

